Low hazard of silver nanoparticles and silver nitrate to the haematopoietic system of rainbow trout

Clark, Nathaniel

http://hdl.handle.net/10026.1/11496

10.1016/j.ecoenv.2018.01.030

Ecotoxicology and Environmental Safety

Elsevier

All content in PEARL is protected by copyright law. Author manuscripts are made available in accordance with publisher policies. Please cite only the published version using the details provided on the item record or document. In the absence of an open licence (e.g. Creative Commons), permissions for further reuse of content should be sought from the publisher or author. 


\title{
Low hazard of silver nanoparticles and silver nitrate to the haematopoietic system of rainbow trout
}

\author{
Nathaniel J. Clark, Benjamin J. Shaw, Richard D. Handy* \\ School of Biological and Marine Sciences, University of Plymouth, Plymouth, United Kingdom
}

\section{ART ICLE INFO}

Keywords:

Nanomaterials

Immunity

Blood smears

Spleen prints

\begin{abstract}
A B S T R A C T
Silver nanoparticles (Ag NPs) are known for their antibacterial properties and are used in a growing number of nano-enabled products, with inevitable concerns for releases to the environment. Nanoparticles may also be antigenic and toxic to the haematopoietic system, but the immunotoxic effect of Ag NPs on non-target species such as fishes is poorly understood. This study aimed to assess the effect of Ag NP exposure via the water on the haematopoietic system of rainbow trout, Oncorhynchus mykiss, and to determine whether or not the hazard from $\mathrm{Ag}$ NPs was different from that of $\mathrm{AgNO}_{3}$. Fish were exposed for 7 days to a control (dechlorinated Plymouth freshwater), dispersant control, $1 \mu \mathrm{g} 1^{-1} \mathrm{Ag}$ as $\mathrm{AgNO}_{3}$ or $100 \mu \mathrm{g}^{-1} \mathrm{Ag}$ NPs. Animals were sampled on days 0,4 and 7 for haematology, tissue trace metal concentration, biochemistry for evidence of oxidative stress/ inflammation in the spleen and histopathology of the blood cells and spleen. The Ag NP treatment significantly increased the haematocrit, but the haematological changes were within the normal physiological range of the animal. Thrombocytes in spleen prints at day 4, and melanomacrophage deposits at day 7 in the spleen, of Ag NP exposed-fish displayed significant increases compared to all the other treatments within the time point. A dialysis experiment confirmed that dissolution rates were very low and any pathology observed is likely from the NP form rather than dissolved metal released from it. Overall, the data showed subtle differences in the effects of Ag NPs compared to $\mathrm{AgNO}_{3}$ on the haematopoietic system. The lack of pathology in the circulating blood cells and melanomacrophage deposits in the spleen suggests a compensatory physiological effort by the spleen to maintain normal circulating haematology during Ag NP exposure.
\end{abstract}

\section{Introduction}

In addition to naturally occurring deposits, silver is introduced into the aquatic environment through anthropogenic activities including those of the photographic and electrical industries (Purcell and Peters, 1998). The toxicology and ecophysiology of dissolved silver $\left(\mathrm{Ag}^{+}\right)$has been relatively well studied in freshwater fish (review, Hogstrand and Wood, 1998). Dissolved silver exerts toxic effects via the fish gill and a Biotic Ligand Model has been developed to predict acute toxicity, depending on the water chemistry (Bury et al., 1999; Hogstrand et al., 2003; Bielmyer et al., 2007). The acute metal toxicity of dissolved silver is characterised by silver ion uptake at the gill epithelium with subsequent disturbances to sodium homeostasis and inhibition of the branchial $\mathrm{Na}^{+} / \mathrm{K}^{+}$-ATPase (Morgan et al., 1997). Defects in acid-base balance via interference with cytoplasmic carbonic anhydrase can also occur (Morgan et al., 1997). Ultimately, during acute toxicity, the de- pletion of plasma sodium and respiratory distress (Morgan et al., 1997; Bury et al., 1999) contribute to cardiovascular collapse (Wood et al., 1996).

Advances in material science have led to the development of colloidal forms of metals at the nanoscale, which are one type of engineered nanomaterials (ENMs). The classification of ENMs with respect to hazardous substances is still being debated (e.g., Stone et al., 2010), but they are generally defined as materials with at least one primary dimension between 1 and $100 \mathrm{~nm}$, but other criteria such as the proportion of nanoscale material present in a chemical substance are also considered (European Commission, 2011). For metal oxide ENMs, there is a concern that their toxicity differs from the equivalent dissolved form of the same metal (Shaw and Handy, 2011). Nano forms of silver are a particular concern because some dissolution of $\mathrm{Ag}$ ions from the surface of Ag NPs is observed (e.g. Besinis et al., 2014), and the $\mathrm{Ag}^{+}$ ion is arguably one of the most toxic elements to aquatic species with $\mathrm{LC}_{50}$ values typically in the low $\mu \mathrm{g}^{-1}$ for rainbow trout (Bury et al.,

\footnotetext{
* Corresponding author.

Email address: R.Handy@plymouth.ac.uk (R.D. Handy)
} 
1999). In contrast, the acute toxicity of Ag NPs to juvenile rainbow trout appear to be much less, with a $96 \mathrm{~h} \mathrm{LC}_{50}$ of around $2.16 \mathrm{mg} \mathrm{l}^{-1}$ in freshwater (Johari et al., 2013). Models predict surface water concentrations of Ag NPs in the ng- $\mu g 1^{-1}$ range (Gottschalk et al., 2013) and while these predictions are likely below the acute toxicity thresholds, there are concerns for chronic and sub-lethal effects of Ag NPs. For Ag NP ecotoxicity to fish the focus has been on the gills (metal accumulation, alterations to gene expression, and oxidative damage; Griffitt et al., 2009; Scown et al., 2010) and the expected traditional mechanisms of dissolved metal toxicity (e.g., liver injury; Choi et al., 2010). Immune effects have been less well studied.

The particulate nature of ENMs has raised concerns that they may act as antigens, like viruses or proteins of a similar size. The concerns for modulation of the mammalian immune system by ENMs have been reviewed (Dobrovolskaia and McNeil, 2007), including the occurrence of immunosuppression as well as excessive stimulation of the immune system leading to inflammation and/or hypersensitivity reactions. In mammals, the research effort has focussed on respiratory exposure to ultrafine dusts (e.g., Duffin et al., 2007). These studies show that stiff high-aspect ratio nanofibers can cause asbestos-like inflammation in rodents that may lead to mesothelioma (Poland et al., 2008). The concerns are less for spherical metal particles that may pass through the lung or dissolve, but congestion of the lung as a result of Ag NP exposure has been observed (Schinwald et al., 2012). Less is known about the effects of ENMs on the haematopoietic system and immunity of aquatic species, including fishes (Handy et al., 2011; Jovanović and Palić, 2012). Teleost fishes, unlike mammals do not have discrete immune organs such as lymph nodes and thymus, although they have groups of cells (as yet not all identified) that may have analogous functions in different parts of the body. In trout, the haematopoietic system comprises the spleen, immune-like functions in cells clustered in the head kidney and elsewhere, as well as the blood cells. There is also evidence of ENM accumulation within the haematopoietic organs of fish. For example, Boyle et al. (2013) intravenously injected rainbow trout with $50 \mu \mathrm{g} \mathrm{ml}^{-1} \mathrm{TiO}_{2}$ over a $96 \mathrm{~h}$ period and reported significant accumulation of titanium in the spleen compared to bulk and control treatments. Similar to mammals, teleost fish have a range of different white blood cells and antibodies present in the cardiovascular system (reviews; Rice, 2001; Handy et al., 2011).

There are a few studies demonstrating potential effects of ENMs on the immune cells of trout. For example, Klaper et al. (2010) used rainbow trout macrophage cell cultures to show that additions of $0.1-10 \mu \mathrm{g} \mathrm{ml}^{-1}$ of functionalized carbon nanotubes cause dose-dependent up regulation of inflammatory cytokines in a similar way to lipopolysaccharide (LPS) positive controls. However, studies assessing $\mathrm{Ag} \mathrm{NP}$ or dissolved silver (as $\mathrm{Ag}^{+}$or otherwise) on the immune functions of fish are sparse. Exposure of fresh suspensions of red blood cells from trout to high concentrations of Ag NPs (3.1-31 $\mu \mathrm{g} \mathrm{ml}^{-1}$ ) for $48 \mathrm{~h}$ causes lactate dehydrogenase (LDH) leakage and haemolysis (Massarsky et al., 2014). At least demonstrating that Ag NPs can be hazardous to the blood cells in vitro. A few in vivo studies are currently available that report some effects of $\mathrm{Ag}$ NPs on some parts of the haematopoietic system. Bruneau et al. (2016) exposed rainbow trout to a $10 \%$ (v/v) dilution of wastewater effluent with a Ag NP mass concentration of $40 \mu \mathrm{g} 1^{-1}$ for $96 \mathrm{~h}$ and found no decrease in lymphocyte or macrophage viability extracted from the pronephros. However, there was a significant decrease in the phagocytic activity of the isolated macrophages in the Ag NP treatment compared to unexposed controls and a $\mathrm{AgNO}_{3}$ treatment. There was also increased cyclo-oxygenase activity in the livers of the fish (Bruneau et al., 2016), that could be interpreted as early evidence of inflammatory pathway activation. Katuli et al. (2014) also showed that acute exposure of zebrafish to $6.76 \mathrm{mg}^{-1}$ of Ag NPs for four days could cause biochemical disturbances to the blood including $\mathrm{NaCl}$ depletion, elevated cortisol and glucose, and inhibition of erythrocyte acetylcholinesterase activity. However, more com- plete in vivo measurements on the immune cells of fish blood are needed, and the effects of Ag NPs on the spleen of fishes is unclear. The aim of this study was to investigate the toxic effects of Ag NPs on the haematopoietic system of rainbow trout (Oncorhynchus mykiss) following a seven day waterborne exposure, and to determine whether the immune hazard for the nano compared to metal salt forms of silver are different. Animals were sampled on day 0, 4 and 7 for haematology (haematocrit, haemoglobin, total red and white cell counts) to overview the status of the blood. In addition, blood smears and spleen prints were collected to explore changes in the proportion of stored and circulating immune cells as well as cell morphology. Histological examination of the spleen enabled some considerations of functional integrity of this central organ of the haematopoietic system as well as anatomical evidence for inflammation. Oxidative stress in the spleen was also assessed biochemically by measuring total glutathione (GSH) and thiobarbituric acid reactive substances (TBARS).

\section{Methodology}

\subsection{Experimental design}

Juvenile rainbow trout $(n=138)$ were obtained from Exmoor Fisheries, then held in an aerated, re-circulating aquaria at Plymouth University. Stock fish were fed using a commercial trout feed (BioMar, 1-2 mm size pellets). A photoperiod of $12 \mathrm{~h}$ : $12 \mathrm{~h}$ light and dark was used throughout both the holding and experimental period. Fish weighing $12.3 \pm 0.7 \mathrm{~g}$ (mean \pm S.E.M., $n=120$ ) were graded into twelve 201 experimental aquaria ( $n=10$ fish per tank) and allowed to acclimate for $24 \mathrm{~h}$ prior to experimentation. Fish were not fed $24 \mathrm{~h}$ prior to, or during, the experiment. The entire experiment was subject to ethical approval according to the Home Office Scientific Procedures Act (1986) in the U.K. and the fish were inspected by an independent specialist on fish welfare and/or veterinary surgeon. O. mykiss were exposed, for 7 days, in triplicate tanks to one of four conditions: control (freshwater only), dispersant control $(0.001 \%$ of $4 \%$ polyoxyethylene glycerol trioleate and polyoxyethylene [20] sorbitan momo-laurat [Tween 20]), $1 \mu \mathrm{g} 1^{-1} \mathrm{Ag}$ as silver nitrate or $100 \mu \mathrm{g} 1^{-1}$ of Ag NPs. The Ag NP concentration was chosen after considering the $96 \mathrm{~h} \mathrm{LC}_{50}$ of around $137 \mu \mathrm{g} \mathrm{l}^{-1}$ for zebrafish larvae in our laboratory (Shaw et al., 2016), and allowing for differences in water temperature and body size and the notion that the larger juvenile rainbow trout were likely to be less sensitive, a sub-lethal concentration of $100 \mu \mathrm{g}^{-1}$ was selected. The exposure duration of one week was chosen to enable time for blood parameters to change, but also to minimise the exposure (i.e., not several weeks) in compliance with ethical approval. The Ag NP was supplied pre-dispersed, and so to account for any toxic effects of the detergents present, a dispersant control of $0.001 \%$ was included to reflect the concentration of the dispersing agent in the Ag NP treatment. The study aimed to be sub-lethal for all treatments so that the biological effects were comparable. A sub-lethal value for the silver nitrate concentration was derived from published data. The $\mathrm{LC}_{50}$ of silver nitrate ranges between 2.9 and $12.7 \mu \mathrm{g} 1^{-1}$ for rainbow trout, depending on water chemistry (Bury et al., 1999). Therefore using a mass concentration of $100 \mu \mathrm{g}^{-1}$ of silver nitrate to match the same test concentration of the Ag NPs was not viable, and to ensure a sub-lethal response $1 \mu \mathrm{g} 1^{-1}$ of $\mathrm{AgNO}_{3}$ was used.

Water changes of $80 \%$ of the total volume were carried out every $12 \mathrm{~h}$ to maintain water quality and to ensure Ag NP exposure. Water samples were collected after the morning water changes, and before the evening water changes, for $\mathrm{pH}$ (Hanna $\mathrm{HI} \mathrm{pH}$ meter), dissolved and saturated oxygen (Hach HQ 40d multi), total ammonia (HI 95715, Hanna Instruments), total $\mathrm{Ag}, \mathrm{Ca}^{2+}, \mathrm{Na}^{+}$and $\mathrm{K}^{+}$concentrations (using inductively coupled plasma mass spectrometry, see below). Additional water samples were taken $6 \mathrm{~h}$ after each water change to check for early losses of silver from the water column. There were no tank effects 
between general water quality parameters, so the data were pooled. Values were (means \pm SEM, $n=27-144$ ); total ammonia: $0.25 \pm 0.03 ; \mathrm{pH}$, $6.98 \pm 0.01$; dissolved oxygen, $9.90 \pm 0.07 \mathrm{mg} \mathrm{1}^{-1}$; oxygen saturation, $96.6 \pm 0.13 \%$; temperature: $13.5 \pm 0.1{ }^{\circ} \mathrm{C}$. The electrolyte composition of dechlorinated, filtered, Plymouth freshwater was $10.07 \pm 0.06,1.47$ \pm 0.01 and $17.64 \pm 0.17 \mathrm{mg} \mathrm{l}^{-1}$ for $\mathrm{Na}^{+}, \mathrm{K}^{+}$and $\mathrm{Ca}^{2+}$, respectively.

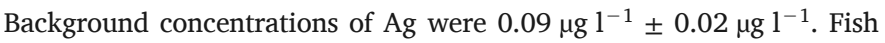
were randomly sampled on day 0,4 and 7 for haematology, biochemistry and histology (see below).

\subsection{Stock solutions and dosing}

The Ag NPs (NM-300K) were supplied by the Joint Research Council as part of the European Commissions' MARINA Project, with the manufacturer's information stating a particle size of approximately $15 \mathrm{~nm}$, with $99 \%$ of the particles being $<20 \mathrm{~nm}$. Transmission electron microscopy (TEM, JEOL 1200EXII) at Plymouth determined a primary particle size of $15.5 \pm 2.4 \mathrm{~nm}$ (mean $\pm \mathrm{SD}, n=156$; Fig. $1 \mathrm{~A}$ ) and no other metal impurities were detected in the material as supplied. A stock of $400 \mathrm{mg} \mathrm{l}^{-1}$ of the Ag NPs was made by adding $197 \mu \mathrm{l}$ of the liquid supplied by the manufacturer into a volumetric flask, which was then filled to $50 \mathrm{ml}$ with ultrapure water (Millipore, $18.2 \mathrm{M} \Omega-\mathrm{cm}$ resistivity, ion free and unbuffered) and sonicated (35-kHz frequency, Fisherbrand FB11010, Germany) for $2 \mathrm{~h}$ without the use of additional solvents. Nanoparticle tracking analysis (Nanosight LM10, Nanosight U.K.) revealed mean aggregate hydrodynamic diameters of $60 \pm 41 \mathrm{~nm}$ with a mode of $34 \mathrm{~nm}(n=3$, Fig. $1 \mathrm{~B})$ in a $1 \mathrm{mg}^{-1}$ dispersion in ultrapure water. Nanoparticle Tracking Analysis could not be conducted reliably in the Plymouth freshwater at the selected test concentration of the $\mathrm{Ag}$ NPs due to the background of natural colloids in the water. For the silver nitrate control, a $4 \mathrm{mg} \mathrm{l^{-1 }}$ stock of $\mathrm{Ag}$ as $\mathrm{AgNO}_{3}$ (Sigma-Aldrich) was prepared in a two-step process. A $1 \mathrm{gl}^{-1}$ solution was
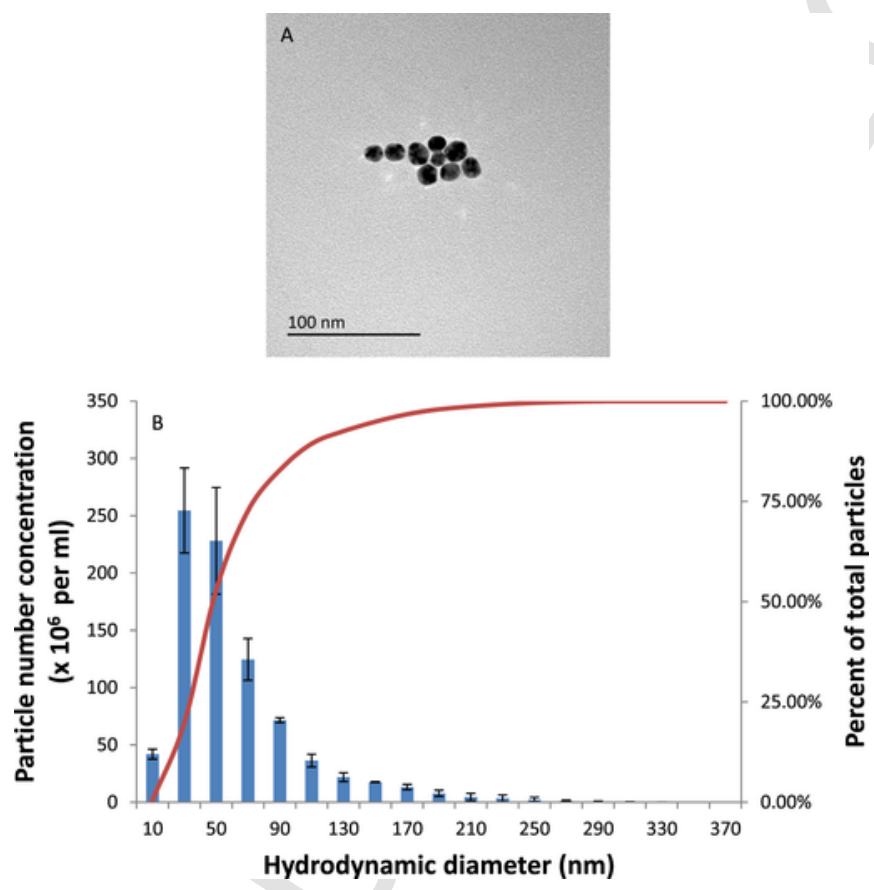

Fig. 1. Primary particle size and particle size distribution of a $1 \mathrm{mg} 1^{-1} \mathrm{Ag}$ NP dispersion in ultrapure water. (A) Transmission electron micrograph showing Ag NPs with a mean primary particle size of $15.5 \pm 2.4 \mathrm{~nm}$ (mean $\pm \mathrm{SD}, n=156$ particles counted) and (B) Particle size distribution measured by Nanoparticle Tracking Analysis (NTA, Nanosight LM10) in a $1 \mathrm{mg} \mathrm{l}^{-1}$ dispersion showing the hydrodynamic diameters and particle number concentration at each bin size (bars \pm standard error) and the cumulative percent of the total particles measured (solid line) in the dispersion in ultrapure water. The natural background of colloids in the Plymouth freshwater and the detection limits of NTA prevented reliable attempts to measure the dispersion during the experiment. made by dissolving $1.575 \mathrm{~g}$ of $\mathrm{AgNO}_{3}$ in $1 \mathrm{~L}$ of ultrapure water. Of this, $2 \mathrm{ml}$ was taken and diluted to $500 \mathrm{ml}$ using ultrapure water. The $\mathrm{AgNO}_{3}$ stock was stored in the dark at room temperature when not in use. Dosing of tanks was carried out by adding the appropriate volume of the stock chemical within $10 \mathrm{~min}$ following the 9 a.m. and 9 p.m. water changes. The volume of stock added to each tank was reduced pro rata to reflect the $80 \%$ water changes.

\subsection{Haematology and plasma ion analysis}

Haematological and plasma ion analysis were performed as described by Handy and Depledge (1999). Briefly, two fish were randomly selected from each tank ( $n=6$ for initial fish, or as otherwise stated at days 0,4 and 7). The animals were carefully anaesthetised with buffered MS222 after which total fish length and weight was recorded. Blood was extracted via the caudal vein into heparinised syringes. Haematocrit (Hct) was calculated according to Handy and Depledge (1999) using microhaematocrit tubes (13,000 rpm, 2 min, Heraeus pico 17 microcentrifuge) and a Hawksley reader (Hawksley, Sussex, UK). The haemoglobin $(\mathrm{Hb})$ concentration was determined from $20 \mu \mathrm{l}$ of whole blood mixed immediately into $5 \mathrm{ml}$ of Drabkin's reagent. Colour development was measured at $540 \mathrm{~nm}$ (Jenway 7315 spectrophotometer) and compared against cyanmethemoglobin standards. A further $20 \mu \mathrm{l}$ of whole blood was fixed in Dacie's fluid $(0.98 \mathrm{ml})$ for total red and white blood cell counts. Another drop of blood was used for blood smears prepared on glass microscope slides. After $24 \mathrm{~h}$ drying, the blood smears were fixed in $100 \%$ methanol and stained with Giemsa. Slides were then scored for normal and abnormal cells (e.g., cells with a dividing nucleus, shrunken cells and swollen cells). The rest of the blood was centrifuged for $2 \mathrm{~min}$ at 13,000 rpm (Micro Centaur MSE) and the plasma frozen at $-80{ }^{\circ} \mathrm{C}$ until required. Plasma $\mathrm{Na}^{+}$and $\mathrm{K}^{+}$concentration was determined using a Corning 420 Flame Photometer as described by Burke et al. (2003).

Spleen prints were prepared as described by Peters and Schwarzer (1985), although these latter authors used the term 'spleen smear', the procedure is in fact to make a print of cells from the spleen. Briefly, spleens were removed from anesthetised fish, carefully cut in half and the prints prepared by pressing the exposed section of tissue onto a glass microscope slide (multiple presses per spleen). Samples were allowed to air dry for $24 \mathrm{~h}$ before fixation in 100\% methanol. Once dry, slides were immersed in BDH buffer (tablets, pH 6.8), May-Grünwald stain (Sigma, 32856) and buffered Giemsa solution and allowed to dry. At least 200 normal cells were counted and the relative percentages calculated (as well as abnormal cells; Peters and Schwarzer, 1985).

\subsection{Water and tissue ion analysis}

Water sampling and tissue ion analysis were performed as described by Shaw et al. (2012). Briefly, water samples were taken to determine $\mathrm{Na}^{+}, \mathrm{K}^{+}, \mathrm{Ca}^{2+}$ and total silver concentrations within tanks from the treatments using inductively coupled plasma mass spectrometry (ICP-MS) against acidified matrix-matched standards and with blanks of $5 \%$ nitric acid in each sample run.

For the tissues, fish were anaesthetised (as above) and dissected to remove the spleen. Gills and liver from fish collected at day 7 from all treatments were also used to confirm aqueous exposure and internalisation of total Ag. The gill tissues were copiously rinsed with ultrapure water to remove externally bound $\mathrm{Ag}$ and clean instruments were used to collect organs from the body cavity to prevent cross-contamination during dissection. Tissue samples were digested in $2 \mathrm{ml}$ of concentrated nitric acid for $2 \mathrm{~h}$ in a water bath at $70{ }^{\circ} \mathrm{C}$ following Shaw et al. (2012). Digests were then cooled and diluted to $8 \mathrm{ml}$ with ultrapure deionised water. Procedural blanks of acid digestion with no tissue were included in the methodology. Samples were then analysed for total $\mathrm{Mn}, \mathrm{Fe}$ and $\mathrm{Ag}$ using ICP-MS and total $\mathrm{Zn}, \mathrm{Ca}, \mathrm{Mg}$, Na and $\mathrm{K}$ using 
inductively coupled plasma optical emission spectrometry (ICP-OES). The standards were matrix matched for acidity and ionic strength as close as possible to the samples. Instrument blanks of nitric acid and also standards were included in the sample runs to correct for instrument drift. The detection limits of each analyte were determined from three times the standard deviation of the blanks. The detection limits for the cations measured by ICP-OES were $50 \mu \mathrm{g} 1^{-1}$ or less depending on the analyte, and the detection limit for Ag by ICP MS was around $0.004 \mu \mathrm{g} 1^{-1}$ depending on the sample matrix.

\subsection{Biochemistry}

Biochemical analysis was performed as described by Smith et al. (2007). Briefly, fish were anaesthetised on day 0, 4 and 7 using buffered MS222. Whole spleens were dissected and immediately snap frozen and stored at $-80{ }^{\circ} \mathrm{C}$ until required for biochemistry. Spleens were homogenised into four volumes $(2.0 \mathrm{ml})$ of ice cold isotonic buffer [in mmol 1 ${ }^{-1} ; 300$ sucrose, 0.1 ethylenediamine tetra acetic acid (EDTA), 20 (4-(2-hydroxyethyl)piperazine-1-ethane sulfonic acid (HEPES)), adjusted to $\mathrm{pH} 7.8$ with a few drops of Tris (2-amino-2-hydroxylmethyl-1,3-propanediol)]. Crude homogenates were stored at $-80{ }^{\circ} \mathrm{C}$ until required for analysis of thiobarbituric acid reactive substances (TBARS) and total glutathione (GSH). For TBARS $120 \mu$ of homogenate was used and compared to standards of 0 (blank), 0.5-25.0 $\mu \mathrm{mol} 1^{-1}$ of 1,1,3,3-tetra-ethoxypropane. For total GSH, $20 \mu$ of homogenate was used for the kinetic determination of GSH. Both assays were conducted exactly as Smith et al. (2007) and absorbances (Versa Max micro plate reader) were measured in 96-well plates in triplicate.

\subsection{Histopathology}

This was performed as described by Smith et al. (2007). Briefly, at days 0 and 7 ( $n=6$ fish per treatment), fish were anaesthetised using buffered MS222, following which they were dissected for whole spleens. Organs were placed in individual vials containing buffered formal saline (Di sodium hydrogen orthophosphate monohydrate, sodium phosphate monobasic monohydrate, $36.6 \%$ formaldehyde). Tissues were processed and stained for routine wax histology. Spleen examinations were made at $5 \mu \mathrm{m}$ and stained with Mallory's Trichrome. Photographs were taken with an Olympus Vanox $\mathrm{T}$ microscope with Olympus digital camera (C-2020 Z). Slides were processed in batches of treatments with controls to eliminate staining artefacts between treatments.

Quantitative histopathological measurements of the spleen were made by assessing fractional areas of the spleen in randomly selected areas using the point counting method described by Weibel et al. (1966). The fractional volume (area) $\mathrm{V}_{\mathrm{i}}=\mathrm{P}_{\mathrm{i}} / \mathrm{P}_{\mathrm{T}}$, where $\mathrm{P}_{\mathrm{i}}$ is the number of points counted and $\mathrm{P}_{\mathrm{T}}$ is the total number of points on the counting grid. This method was used to determine the relative proportions of red pulp, white pulp and sinusoidal space with counts of melanomacrophage also noted, similar to our previous studies on trout with ENMs (Al-Bariuty et al., 2013).

\subsection{Dialysis experiment}

Dialysis experiments were carried out to assess the dissolution rate of Ag NPs in dechlorinated Plymouth freshwater and ultrapure water. The method was based on Besinis et al. (2014). Glassware was acid washed using $5 \%$ nitric acid prior to use. The dialysis tubing (cellulose membrane with a molecular weight cut off at 12,000 Da, Sigma Aldrich) was soaked in ultrapure overnight, following which it was made into dialysis bags containing $8 \mathrm{ml}$ of $100 \mathrm{mg} \mathrm{l}^{-1} \mathrm{Ag}$ NPs using mediclips. After bags were filled, they were added to beakers containing $492 \mathrm{ml}$ of the appropriate media (dechlorinated Plymouth freshwa- ter or ultrapure water), giving a total volume of $500 \mathrm{ml}$. Each experiment was carried out in triplicate for $24 \mathrm{~h}$ at room temperature. A multipoint stirrer (Ro 15p power, Ika-Werke GmbH and Co. KG, Staufen, Germany) was used to gently agitate the media during the experimental period. Samples from the media of each beaker were collected at $0,0.5$, $1,2,4,6$ and $24 \mathrm{~h}$ as well as the dialysis tubing contents at the end of the experiment for determination of Ag concentration (ICP-MS). Glassware was monitored throughout the experiment for ion leakage by using dialysis blanks (dialysis bags also containing the external media).

\subsection{Statistics}

All data were analysed using Statgraphics Centurion XVI and dialysis curves fitted as appropriate using SigmaPlot 11.0. Data were checked for descriptive statistics and normality (skewedness and kurtosis), with deviations of more than \pm 2 considered as non-normal distribution. No tank effects were observed in the data, and so data were pooled by treatment. Treatment effects or time-effects were analysed by two-way ANOVA after evaluating the data for unequal variance using Bartlett's test. For parametric data ANOVA was applied, followed by Tukey HSD post hoc test to confirm the location of significant differences ( $P$ $<0.05)$. For non-parametric data, the Kruskal-Wallis test was used with notched box and whisker plots to locate differences. All analysis used the default level for statistical significance in the software.

\section{Results}

\subsection{Confirming aqueous exposure to silver and particle behaviour}

Waterborne silver exposure was confirmed by measuring the total $\mathrm{Ag}$ concentrations in the tanks at 0,6 and $12 \mathrm{~h}$ leading up to each water change and re-dosing of the test system. No significant differences were observed between tanks within time points and treatment for total Ag concentration, and so data were pooled by time point within treatment. The silver concentrations within the control and dispersant control treatments were not statistically different over the time period and remained low $\left(<0.09 \mu \mathrm{g} 1^{-1}\right.$ in control and $<0.04 \mu \mathrm{g} 1^{-1}$ in dispersant control at 0,6 and $12 \mathrm{~h}$, respectively within water changes). The total silver present in experimental tanks (mean \pm SEM, $n=14$ ) were $0.96 \pm 0.31,0.81 \pm 0.13$ and $0.62 \pm 0.06 \mu \mathrm{g} 1^{-1}$ for $\mathrm{AgNO}_{3}$ treatments at 0,6 , and $12 \mathrm{~h}$ before the next water change (no statistically significant difference, between time points, ANOVA, $P>0.05$ ). The overall mean of measured total silver concentrations in the tanks were $0.76 \pm$ $0.10 \mu \mathrm{g} 1^{-1}$ during the whole experiment, demonstrating some loss of the nominal exposure concentration. Despite the water changes some settling of Ag NPs was apparent in the NP treatment. The average total silver concentration in Ag NP treated tanks (mean \pm SEM, $\mathrm{n}=14$ ) were $84.19 \pm 2.14,64.71 \pm 5.99$ and $56.67 \pm 4.72 \mu \mathrm{g}^{-1}$ in the Ag NP treatments $(0,6$ and $12 \mathrm{~h}$, respectively), which resulted in the samples at 6 and $12 \mathrm{~h}$ being statistically lower than that initially measured in the tank at the start (ANOVA, $P>0.05$ ). Overall, the mean for the 7 days exposure was $65 \pm 4.46 \mu \mathrm{g} 1^{-1}$.

Tissue samples of the gill, liver and spleen were taken to confirm aqueous exposure and internalisation of $\mathrm{Ag}$ at day 7 of the experiment, which demonstrated treatment and some material effects. At day 7 , the control and dispersant control gills had total $\mathrm{Ag}$ concentrations below the limit of detection (equating to between 2.8 and $53.0 \mathrm{ng} \mathrm{g}^{-1}$ dry weight of tissue). The gills of fish from the day $7 \mathrm{Ag}$ NP treatment had significantly more total $\mathrm{Ag}$ (mean \pm S.E.M, $3527.1 \pm 392.1 \mathrm{ng} \mathrm{g}^{-1}$ dry weight) compared to the animals from the $\mathrm{AgNO}_{3}$ treatment $(746.1 \pm$ $198.6 \mathrm{ng} \mathrm{g}^{-1}$ dry weight, ANOVA, $\left.P<0.05\right)$. Some background levels of $\mathrm{Ag}$ were detected in the liver of control and dispersant control tissues. However, these values were significantly less (Kruskal-Wallis, $P$ 
$<0.05$ ) than those of fish exposed to either $\mathrm{AgNO}_{3}$ or $\mathrm{Ag}$ NPs (data are mean \pm S.E.M., control, $0.31 \pm 0.05$; dispersant control, $0.32 \pm 0.12$; $\mathrm{AgNO}_{3}, 17.73 \pm 4.87$; and $\mathrm{Ag}$ NPs, $51.51 \pm 12.61 \mu \mathrm{g} \mathrm{g}{ }^{-1}$ dry weight tissue). No material-effect was observed. Spleens from the initial fish at time zero and those at day 7, regardless of treatment showed total Ag concentrations below the limit of detection $\left(<3 \mathrm{ng} \mathrm{g}^{-1}\right)$.

A dialysis experiment was conducted to assess dissolved Ag release from Ag NPs in ultrapure water and Plymouth freshwater. The dissolution was low and curves for the total cumulative $\mathrm{Ag}$ released into the medium (see Supplement data) followed a rectangular hyperbola achieving maximum apparent dissolved silver release of 84.7 and 52.4 of silver metal (absolute amount) in ultrapure water and Plymouth freshwater respectively; representing $10.6 \%$ and $6.5 \%$ of the initial total silver content in the dialysis bags. The fastest release of total dissolved silver was within the first $0.5 \mathrm{~h}$, with maximum rates of dissolution of 0.62 and $0.61 \mu \mathrm{g} \mathrm{min}{ }^{-1}$ in ultrapure water and Plymouth freshwater, respectively.

\subsection{Haematology and plasma ions}

Some statistically significant haematological differences were observed between $\mathrm{AgNO}_{3}$, or Ag NPs, when compared to the control treatments; but no differences between silver materials were observed (Table 1). At day 4, total red blood cell counts of fish from the control and dispersant control were significantly higher compared to both $\mathrm{AgNO}_{3}$ and Ag NP treatments (ANOVA, $P<0.05$ ), but no differences were observed between the two silver materials. There were no statistical differences between treatment at any given time point, or time-effects within treatments in total white blood cell counts (ANOVA, $P>0.05$ ). Haematocrit values were higher in fish exposed to Ag NPs than controls throughout, with transient differences to the dispersant control (ANOVA, $P<0.05$ ). Haemoglobin concentration showed no treatment dependent affects at day 4 and day 7 in fish, although there were some time effects within treatments (Table 1).

Similar to the haematology, some statistical differences in plasma ion $\mathrm{Na}^{+}$and $\mathrm{K}^{+}$were observed between treatments after exposure to
$\mathrm{AgNO}_{3}$ and $\mathrm{Ag} \mathrm{NP}$, with some material-type effects (Table 1). Plasma $\mathrm{Na}^{+}$concentrations in the animals from the Ag NP treatment were significantly lower than controls, whereas those from the $\mathrm{AgNO}_{3}$ treatment showed transient reductions compared to controls within the same day (ANOVA, $P<0.05$ ). At day $7, \mathrm{Ag}$ NP-exposed fish had a plasma $\mathrm{Na}^{+}$concentration that was significantly lower than that of $\mathrm{AgNO}_{3}$-exposed fish at the same time point (Table 1). Plasma $\mathrm{K}^{+}$concentration showed treatment and time within treatment dependent changes. At day 7, plasma $\mathrm{K}^{+}$in $\mathrm{Ag} \mathrm{NP}$-exposed fish was significantly higher than those of the $\mathrm{AgNO}_{3}$ treatment (ANOVA, $P<0.05$; Table 1). There were no differences between treatment, or time within treatment, for the plasma osmolarity data (ANOVA, $P<0.05$ ).

Some statistical differences were observed in trace metal concentration of the spleen between days within treatment, but no material-type affects were observed. Spleen $\mathrm{Zn}$ concentration of $\mathrm{AgNO}_{3}$-exposed fish was significantly lower than the unexposed control (means $\pm \mathrm{SEM} ; \mathrm{AgNO}_{3}$ treatment, $0.42 \pm 0.27 \mu \mathrm{mol} \mathrm{g}{ }^{-1}$ dry weight tissue; control, $2.52 \pm 0.52 \mu \mathrm{mol} \mathrm{g}^{-1}$ dry weight tissue; ANOVA, $\left.P<0.05\right)$. Exposure to $\mathrm{Ag} \mathrm{NPs}$, but not $\mathrm{AgNO}_{3}$, caused some depletion of $\mathrm{K}^{+}$and $\mathrm{Mg}^{2+}$ from the spleen (ANOVA or Kruskal-Wallis, $P<0.05$ ). For example, spleen $\mathrm{K}^{+}$concentrations in $\mathrm{Ag}$ NP-exposed fish at the end of the experiment were $90.2 \pm 28.6 \mu \mathrm{mol} \mathrm{g}^{-1}$ dry weight tissue compared to 621.3 \pm 166.4 in the control. The spleen $\mathrm{Mg}^{2+}$ concentrations in $\mathrm{Ag}$ NP-exposed fish and controls at the end of the experiment were $8.1 \pm 2.1$ and $52.7 \pm 14.3 \mu \mathrm{mol} \mathrm{g}{ }^{-1}$ dry weight tissue respectively. The $\mathrm{Mg}^{2+}$ concentration in the spleens of Ag NP-exposed fish were also lower than dispersant controls (dispersant control, $63.0 \pm 22.9 \mu \mathrm{mol} \mathrm{g}^{-1}$; and $\mathrm{Ag} \mathrm{NP}$, $8.1 \pm 2.1 \mu \mathrm{mol} \mathrm{g}^{-1}$, Kruskal-Wallis, $P<0.05$ ). The Ag NP treatment also depleted $\mathrm{Mn}$ in the spleen by day 7 (control, $75.93 \pm 20.64$; Ag NP treatment, $15.22 \pm 6.91 \mu \mathrm{mol} \mathrm{g}{ }^{-1}$ dry weight tissue; ANOVA, $P<$ 0.05). However, no significant differences were observed between the type of $\mathrm{Ag}$ material on spleen Mn concentrations.

In the blood smears, statistical differences were observed between treatments, and some time-effects were found within treatments for erythrocyte, erythroblasts and lymphocyte counts, but no material-type effects were observed (Fig. 2). Erythrocyte counts at day 4 for fish from

Table 1

Haematology and plasma ions from rainbow trout exposed to $1 \mu \mathrm{g} \mathrm{l}^{-1} \mathrm{Ag}$ as $\mathrm{AgNO}_{3}$ or $100 \mu \mathrm{g} \mathrm{l}^{-1} \mathrm{Ag} \mathrm{NPs}$ for up to 7 days.

\begin{tabular}{|c|c|c|c|c|c|}
\hline \multirow[t]{2}{*}{ Parameter } & \multirow[t]{2}{*}{ Time } & \multicolumn{4}{|l|}{ Treatment } \\
\hline & & Control & Dispersant control & $1 \mu \mathrm{g} 1^{-1} \mathrm{AgNO}_{3}$ & $100 \mu g 1^{-1} \mathrm{Ag} \mathrm{NP}$ \\
\hline \multirow[t]{3}{*}{ Haematocrit (\%) } & 0 & $34.67 \pm 0.80(6)$ & & & \\
\hline & 4 & $28.50 \pm 1.38(6)$ & $25.20 \pm 1.59(5)^{\circ}$ & $26.33 \pm 2.06(6)^{\circ}$ & $33.50 \pm 2.78(6)^{*+\#}$ \\
\hline & 7 & $27.83 \pm 1.52(6)$ & $30.6 \pm 2.84(5)$ & $29.17 \pm 0.83(6)$ & $36.40 \pm 3.08(5)^{*}$ \\
\hline \multirow[t]{3}{*}{ Haemoglobin $\left(\mathrm{g} \mathrm{dl}^{-1}\right)$} & 0 & $6.30 \pm 0.24(6)$ & & & \\
\hline & 4 & $1.82 \pm 0.42(5)^{\circ}$ & $1.74 \pm 0.15(5)^{\circ}$ & $2.00 \pm 0.25(6)^{\circ}$ & $2.47 \pm 0.17(5)^{\circ}$ \\
\hline & 7 & $4.10 \pm 0.55(6)^{\mathrm{T}}$ & $4.02 \pm 0.82(6)^{\mathrm{T}}$ & $3.53 \pm 0.16(6)^{\mathrm{T}}$ & $4.99 \pm 1.10(6)$ \\
\hline \multirow[t]{3}{*}{ Red blood cell count (cells $\times 10^{6} \mathrm{~mm}^{3}$ ) } & 0 & $0.10 \pm 0.03(6)$ & & & \\
\hline & 4 & $0.20 \pm 0.01(6)^{\circ}$ & $0.26 \pm 0.03(4)^{\circ}$ & $0.10 \pm 0.02(6)^{*+}$ & $0.09 \pm 0.02(6)^{*+}$ \\
\hline & 7 & $0.13 \pm 0.00(6)$ & $0.07 \pm 0.02(5)^{\mathrm{T}}$ & $0.10 \pm 0.02(6)$ & $0.09 \pm 0.02(5)$ \\
\hline \multirow[t]{3}{*}{ White blood cell count (cells $\times 10^{3} \mathrm{~mm}^{3}$ ) } & 0 & $0.83 \pm 0.34(6)$ & & & \\
\hline & 4 & $1.40 \pm 0.33(6)$ & $1.85 \pm 0.46(4)$ & $1.22 \pm 0.44(6)$ & $1.22 \pm 0.10(6)$ \\
\hline & 7 & $1.33 \pm 0.72(6)$ & $1.16 \pm 0.23(5)$ & $2.80 \pm 0.62(6)$ & $2.56 \pm 0.53(6)$ \\
\hline \multirow[t]{3}{*}{ Plasma Na $^{+}\left(\mathrm{mmol} \mathrm{l}^{-1}\right)$} & 0 & $144 \pm 2.19$ & & & \\
\hline & 4 & $108.43 \pm 14.43(4)$ & $123.78 \pm 6.03(4)$ & $100.58 \pm 16.85(4) *$ & $80.60 \pm 18.23(5)^{*+\circ}$ \\
\hline & 7 & $111.3 \pm 4.83(5)^{\circ}$ & $114.83 \pm 6.64(4)^{\circ}$ & $111.70 \pm 10.75(4)^{\circ}$ & $83.50 \pm 4.98(3)^{*+\# \circ}$ \\
\hline \multirow[t]{3}{*}{ Plasma K ${ }^{+}\left(\mathrm{mmol} \mathrm{l}^{-1}\right)$} & 0 & $3.15 \pm 0.42(4)$ & & & \\
\hline & 4 & $4.83 \pm 0.53(4)$ & $4.49 \pm 0.27(4)$ & $4.87 \pm 0.10(5)^{\circ}$ & $5.05 \pm 0.03(5)^{\circ}$ \\
\hline & 7 & $3.74 \pm 0.25(5)$ & $4.23 \pm 0.40(4)$ & $3.94 \pm 0.22(4)^{\mathrm{T}}$ & $4.86 \pm 0.00(3)^{* \# \circ \mathrm{T}}$ \\
\hline \multirow[t]{3}{*}{ Osmolarity (mOsm kg ${ }^{-1}$ ) } & 0 & $322.50 \pm 6.49(4)$ & & & \\
\hline & 4 & $276.20 \pm 33.06(5)$ & $284.25 \pm 13.84(4)$ & $267.8 \pm 16.69(5)$ & $276.00 \pm 13.04(5)$ \\
\hline & 7 & $293.17 \pm 20.98(6)$ & $326.00 \pm 31.28(4)$ & $303.40 \pm 16.59(5)$ & $282.00 \pm 31.09(5)$ \\
\hline
\end{tabular}

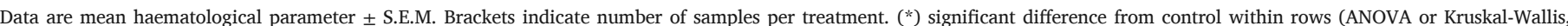

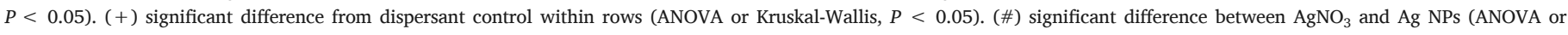

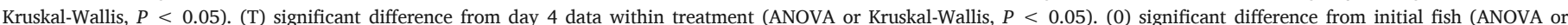
Kruskal-Wallis, $P<0.05$ ). 

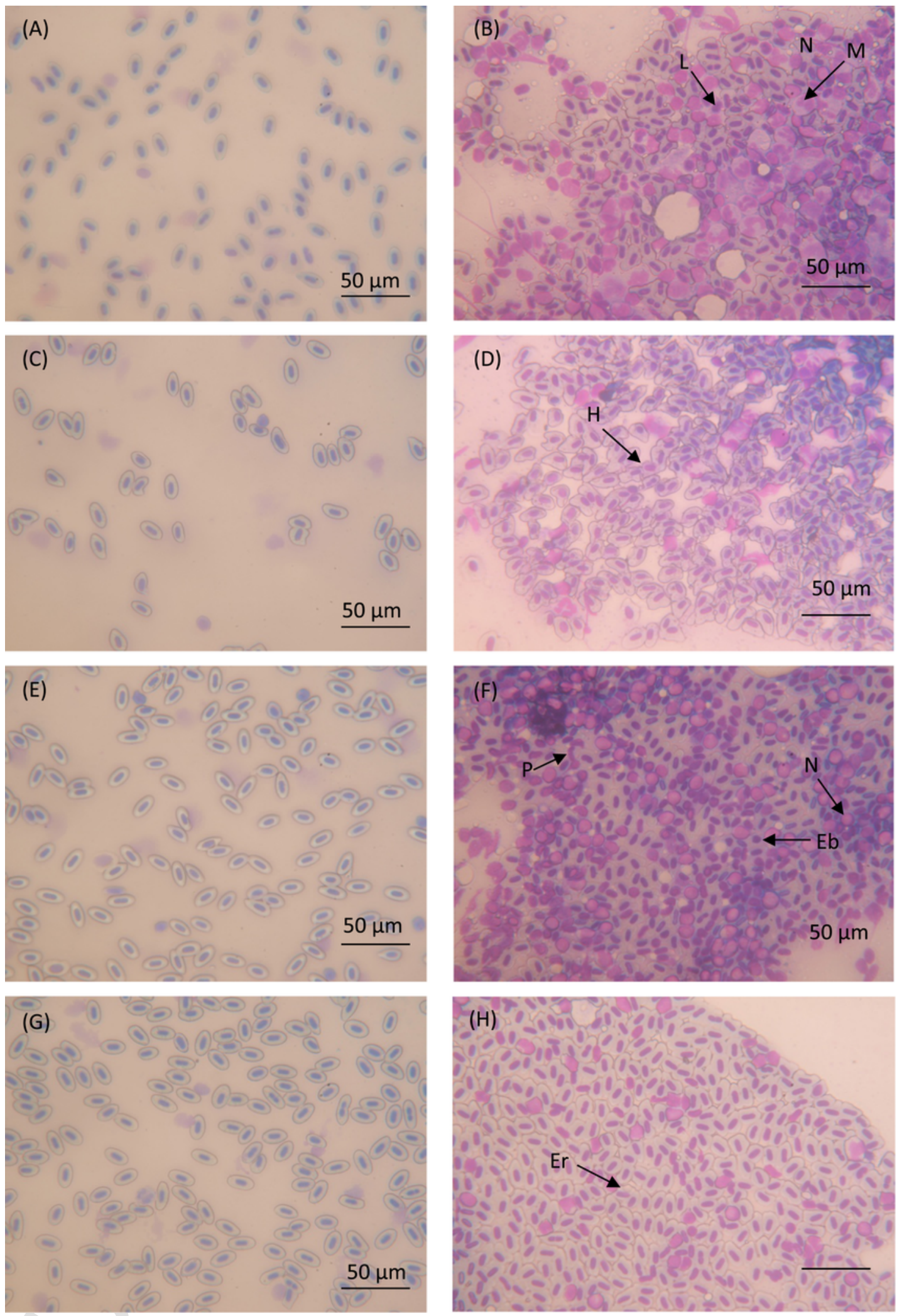

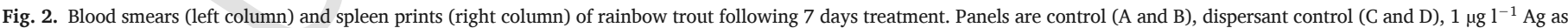

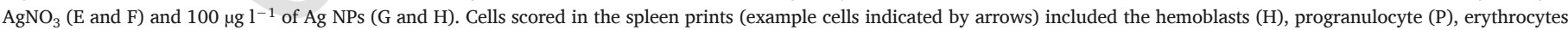

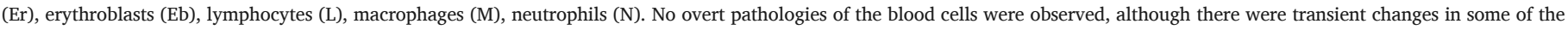
cell counts. 
the dispersant control were significantly lower compared to Ag NP treatment (Kruskal-Wallis, $P<0.05$ ). Also, day 4 erythroblast counts in both the control and $\mathrm{Ag}$ NP treatments were significantly lower compared to the dispersant control (Kruskal-Wallis, $P<0.05$; Table 2). The total number of lymphocytes were counted on the blood smears and showed that Ag NP exposed fish at day 7 had significantly lower counts compared to that of the dispersant control and initial fish. There were some levels of background membrane abnormalities in control and dispersant control fish over time, but no significant difference between silver materials was observed.

Some statistical differences were observed in the total number of erythrocytes, lymphocytes and thrombocytes counted in spleen prints between treatments, and some time-effects within treatments. Notably, some differences between materials occurred (Fig. 2). The spleen print erythroblast counts decreased with exposure time in fish from the $\mathrm{AgNO}_{3}$ treatment (ANOVA, $P<0.05$ ), but not in the Ag NP treatment. The lymphocyte counts of fish from the control treatments showed a transient rise at day 4 compared to all the other treatments (ANOVA, $P<0.05$ ). Some transient changes also occurred in the thrombocytes. At day 4, thrombocyte counts were significantly increased in the $\mathrm{Ag}$ NP treatment compared to those of the control, dispersant control and $\mathrm{AgNO}_{3}$ treatments (material-type effect). No treatment or time effects were seen within hemoblast, progranulocytes or neutrophils counts. Background changes in abnormal cells were evident in control treatments, but no significant difference between silver materials was observed.

\subsection{Histopathology and biochemistry}

There were no treatment effects on the proportions of red pulp and white pulp measured in the spleen, but the values for individual fish did show some variation (Fig. 3). Furthermore, there was no constriction or expansion of the sinusoid space regardless of silver exposure or the form of silver (Kruskal-Wallis, $P<0.05$ ). Melanomacrophage deposits were present in the spleens of control fish, as expected for the normal housekeeping of the spleen to remove damaged cells from the circulation. However, the dispersant and both forms of silver showed some time-dependent increase in melanomacrophage deposits compared to the control (ANOVA or Kruskal-Wallis, $P<0.05$ ). There was also a material type-effect with the Ag NP-exposed fish showing higher melanomacrophage counts than that of the $\mathrm{AgNO}_{3}$ treatment (ANOVA, $P<0.05)$.

Oxidative stress parameters were measured on initial, day 4 and day 7 fish to inform of potential inflammation injury to the spleen tissue. The TBARS concentrations showed some-time dependent changes within treatments, but there was no clear material-type effect. TBARS concentrations in spleen of exposed fish were significantly higher in $\mathrm{AgNO}_{3}$ and $\mathrm{Ag} \mathrm{NP}$ fish after 4 days compared to controls (controls, 0.34 $\pm 0.11 ; \mathrm{AgNO}_{3}, 1.43 \pm 0.44$; and $\mathrm{Ag}$ NPs, $2.11 \pm 0.63 \mathrm{nmol} \mathrm{mg}{ }^{-1}$ protein), but this was transient and lost by the end of the experiment. There were no statistical differences in the total GSH concentration between silver treatments or the dispersion control, although by day 7 all these treatments show a decrease compared to the initial fish (initial fish, 1.11 \pm 0.05 ; day 7 control, $0.71 \pm 0.11$; dispersant control, $0.56 \pm 0.10$; $\mathrm{AgNO}_{3}, 0.75 \pm 0.06$; and $\mathrm{Ag} \mathrm{NPs}, 0.66 \pm 0.16 \mu \mathrm{mol} \mathrm{g}{ }^{-1}$ wet weight tissue, ANOVA, $P<0.05$ ). Total GSH concentrations did not show any difference between silver materials.

\section{Discussion}

This study assessed the effects of $\mathrm{Ag} \mathrm{NPs}$ compared to $\mathrm{AgNO}_{3}$ on the haematopoietic system of rainbow trout. Exposure to $\mathrm{Ag}$ as $\mathrm{AgNO}_{3}$ caused some disturbances in spleen lymphocyte counts. Exposure to $\mathrm{Ag}$ NPs caused significant changes in the Hct, plasma $\mathrm{Na}^{+}$and $\mathrm{K}^{+}$concentrations, as well as alterations in the spleen print thrombocyte and erythrocyte counts. For most parameters, the effects of Ag NPs were equal to or less than the effects of $\mathrm{AgNO}_{3}$.

\subsection{Confirming silver exposure}

Waterborne exposure was confirmed by measuring total silver in the water and in the gills, liver and spleen tissues. The controls and solvent controls showed only trace levels of silver in the water as expected, and in the gills a background similar to that reported in trout by Bruneau et al. (2016). The $\mathrm{AgNO}_{3}$ treatment achieved a measured concentration in the water that was very close to the nominal total concentration. However, the Ag NPs as expected from out previous semi-static exposure with metallic NPs (Cu NPs, Shaw et al., 2012) showed some decline in the measured total silver concentrations in the water column. The stock used for dosing the tanks with Ag NPs showed a good dispersion (Fig. 1), and the decrease in the fish tanks was almost

Table 2

Quantitative analysis of blood smears from rainbow trout exposed to $1 \mu \mathrm{g} \mathrm{1}^{-1} \mathrm{Ag}$ as $\mathrm{AgNO}_{3}$ or $100 \mu \mathrm{g} 1^{-1} \mathrm{Ag} \mathrm{NPs}$ for 4 or 7 days.

\begin{tabular}{|c|c|c|c|c|c|}
\hline Percent of & Time & Treatment & & & \\
\hline cells & (days) & Control & Dispersant & $1 \mu \mathrm{g} \mathrm{l^{-1 }} \mathrm{AgNO}_{3}$ & $100 \mu g l^{-1} \mathrm{Ag} \mathrm{NP}$ \\
\hline \multirow[t]{3}{*}{ Erythrocytes } & 0 & $92.62 \pm 1.40(6)$ & & & \\
\hline & 4 & $92.55 \pm 1.69(3)$ & $79.96 \pm 4.63(5)$ & $89.92 \pm 3.12(5)$ & $92.10 \pm 0.91(5)^{+}$ \\
\hline & 7 & $93.41 \pm 1.80(6)$ & $95.58 \pm 0.65(5)$ & $95.84 \pm 0.71(6)$ & $95.75 \pm 0.86(6)$ \\
\hline \multirow[t]{3}{*}{ Erythroblasts } & 0 & $2.05 \pm 1.07(6)$ & & & \\
\hline & 4 & $1.03 \pm 0.81(3)$ & $4.47 \pm 1.47(5)^{*}$ & $1.58 \pm 0.62(5)$ & $1.24 \pm 0.35(5)^{+}$ \\
\hline & 7 & $0.37 \pm 0.29(6)^{\circ}$ & $0.71 \pm 0.29(5)^{\circ}$ & $0.42 \pm 0.02(6)^{\circ}$ & $0.99 \pm 0.37(6)$ \\
\hline \multirow[t]{3}{*}{ Lymphocytes } & 0 & $1.24 \pm 0.27(6)$ & & & \\
\hline & 4 & $2.15 \pm 0.44(3)$ & $3.88 \pm 1.36(5)$ & $2.12 \pm 0.71(5)$ & $1.72 \pm 0.32(5)$ \\
\hline & 7 & $1.75 \pm 0.81(6)$ & $1.29 \pm 0.42(5)$ & $0.66 \pm 0.30(6)$ & $0.00 \pm 0.00(6)^{+0}$ \\
\hline \multirow[t]{3}{*}{ Macrophages } & 0 & $0.43 \pm 0.36(6)$ & & & \\
\hline & 4 & $1.84 \pm 0.05$ & $2.84 \pm 0.87(5)$ & $0.75 \pm 0.52(5)$ & $1.41 \pm 0.48$ \\
\hline & 7 & $1.61 \pm 0.69(6)$ & $1.01 \pm 0.11(5)$ & $1.14 \pm 0.49(6)$ & $0.97 \pm 0.28(6)$ \\
\hline \multirow[t]{3}{*}{ Neutrophils } & 0 & $0.39 \pm 0.39(6)$ & & & \\
\hline & 4 & $0.16 \pm 0.16(3)$ & $0.28 \pm 0.28(5)$ & $0.41 \pm 0.41$ & $0.56 \pm 0.56(5)$ \\
\hline & 7 & $0.45 \pm 0.45(6)$ & $0.17 \pm 0.17(5)$ & $0.07 \pm 0.07(6)$ & $1.29 \pm 1.29(6)$ \\
\hline \multirow[t]{3}{*}{ Thrombocytes } & 0 & $3.26 \pm 0.80(6)$ & & & \\
\hline & 4 & $2.26 \pm 0.84(3)$ & $8.58 \pm 2.68(5)$ & $5.23 \pm 2.14(5)$ & $2.98 \pm 0.90(5)$ \\
\hline & 7 & $2.41 \pm 0.84(6)$ & $1.24 \pm 0.51(5)$ & $1.87 \pm 0.29(6)$ & $1.00 \pm 0.42(6)$ \\
\hline
\end{tabular}

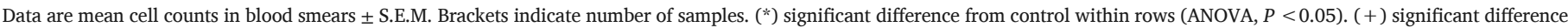
from Dispersant control within rows (ANOVA or Kruskal-Wallis, $P<0.05$ ). (0) significant difference from initial fish (ANOVA, $P<0.05$ ). 

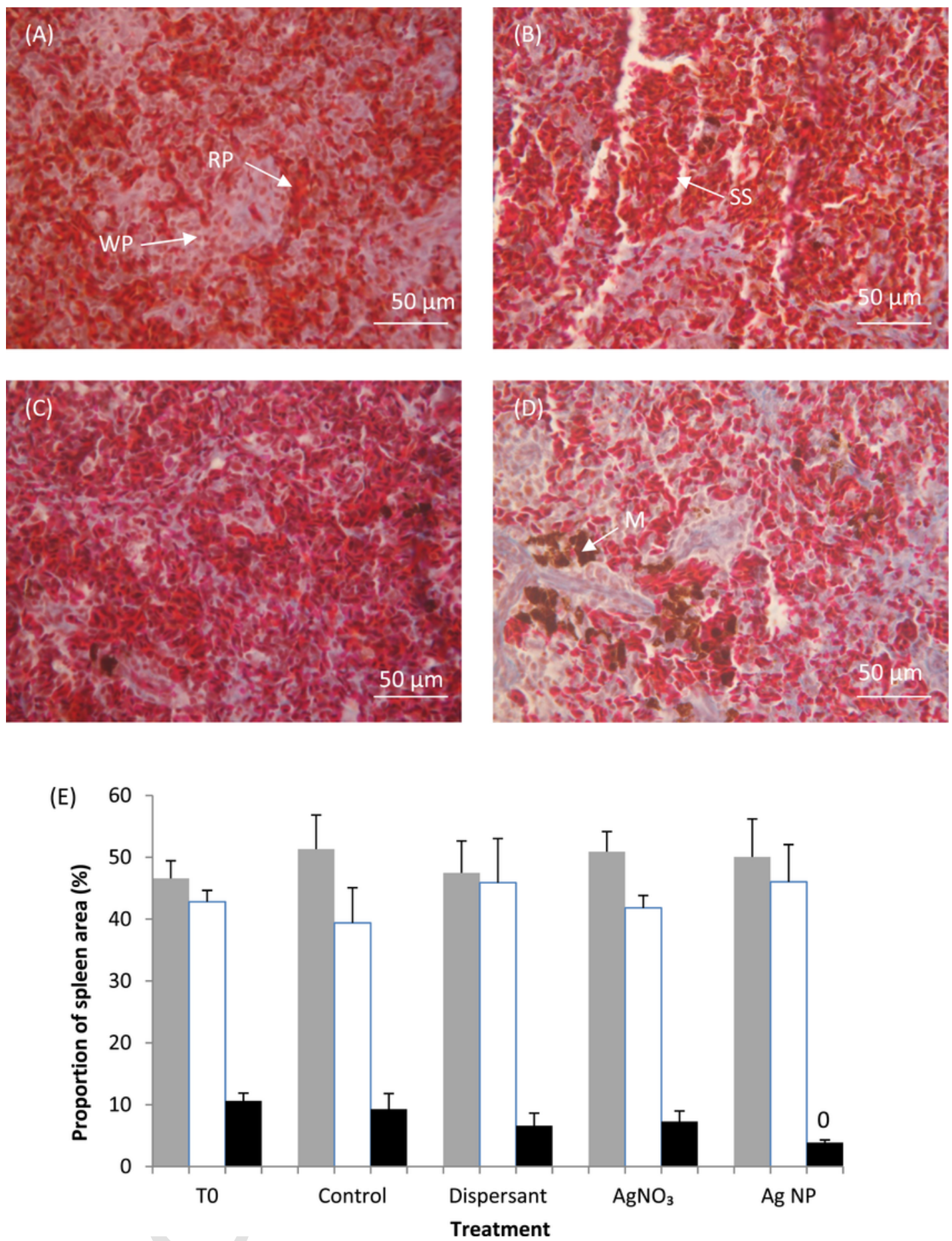

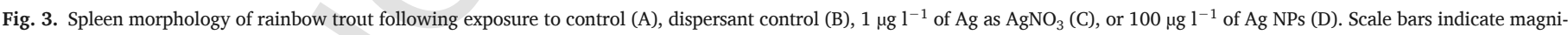

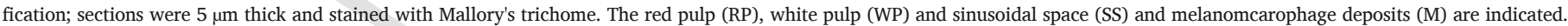

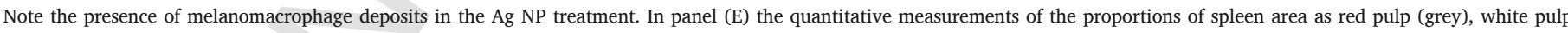

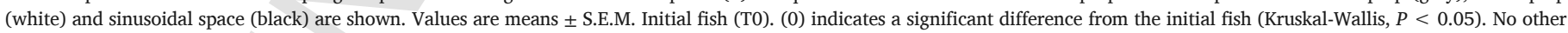
differences were observed.

certainly due to particle settling, resulting in overall silver concentrations of $65 \%$ of the nominal concentration during the exposure. While the exposure was confirmed by measurements of the water, from a perspective of regulatory testing, this would not be within the accepted $100 \pm 20 \%$ nominal concentration criteria for a valid OECD (Organisation for Economic Cooperation and Development) test (Shaw et al., 2016). In terms of ENM testing, Ag NP exposures are especially challenging to maintain (see Shaw et al., 2016) and the dosing achieved here was relatively robust with the regular water changes. Both the $\mathrm{AgNO}_{3}$ and $\mathrm{Ag} \mathrm{NP}$ exposures were sub-lethal with only one mortality in the entire experiment, which occurred in the Ag NP treatment. This was attributed to bullying due to evidence of fin nipping.

The notion of a sub-lethal exposure for Ag NPs was also supported by the dialysis experiment which was conducted to assess total dissolved silver release from the Ag NPs in Plymouth freshwater. The percentage of overall dissolution of silver from the Ag NPs was $6.5 \%$ in 
the dialysis experiments over $24 \mathrm{~h}$. The maximum rate of dissolution was $0.61 \mu \mathrm{g} \mathrm{min}{ }^{-1}$, and even if this maximum dissolution rate were maintained for the duration of the 12 -h period before the next water change, this would equate to a theoretical maximum release of $22 \mu \mathrm{g} 1^{-1}$ of $\mathrm{Ag}$ ions. This clearly did not occur, as there was no evidence of acute toxicity. This apparent lack of free ion toxicity can be attributed to any dissolution slowing in the fixed $20 \mathrm{~L}$ volume of the tank (i.e., reaching equilibrium), some particle settling, but more likely the presence of millimolar concentrations of $\mathrm{Cl}^{-}$ions in the water that would rapidly chelate free silver ions to insoluble $\mathrm{AgCl}$ (see Besinis et al., 2014). Therefore, silver ion toxicity in the water column derived from the Ag NPs is not a likely explanation of the biological effects reported in the present study.

The total Ag in the gill tissues also confirmed that exposures had occurred compared to the controls, and notably the total $\mathrm{Ag}$ in the gills of fish from the Ag NP treatment were around $4 \times$ higher than those from the $\mathrm{AgNO}_{3}$ treatment. This might be expected since the mass concentration of silver in the water for the latter was necessarily lower to maintain a sub-lethal exposure. The acid digestion method used for the tissues can only reveal total Ag, not the form of the silver (and was not intended to do so). Nonetheless both Ag treatments demonstrated internalisation of the metal (form unknown) with elevated total Ag levels in the livers of the fish at the end of the experiment. There was no silver accumulation in the spleen and this is consistent with the findings of Shaw et al. (2012) on Cu NPs, indicating the spleen is not an organ of direct toxicity.

\subsection{Haematology and osmotic disturbances}

The control animals showed normal ranges of haematology and plasma ions (Table 1) that were consistent with our previous reports for juvenile trout in Plymouth freshwater (e.g., Shaw et al., 2012). There were some transient changes in the haemoglobin concentration and red blood cell counts at day 4 (Table 1), but these recovered by day 7 and were within the normal physiological range. There was a gradual decline in plasma $\mathrm{Na}^{+}$in the control fish, which is associated with not feeding the fish during the experiment given that fish preferentially regulate plasma $\mathrm{Na}^{+}$from dietary salt intake (Smith et al., 1989). However, periods without food is normal for trout in the wild, and there was no impact on plasma osmolarity or any evidence of red cell swelling in the controls, showing that the control animals were not osmotically challenged.

Exposure to $\mathrm{AgNO}_{3}$ or $\mathrm{Ag}$ NPs caused a fall in plasma Na${ }^{+}$compared to the time-matched controls. This effect was much greater for the Ag NP treatment, and also with some evidence of cell swelling in the latter (increased Hct, Table 1). The sub-lethal effects of $\mathrm{AgNO}_{3}$ on osmoregulation at the gill are well-known, and the small plasma $\mathrm{Na}^{+}$loss reported here is consistent with passive ion loss through the gills and/or a transient inhibition of the branchial $\mathrm{Na}^{+}$pump (Wood et al., 1996). The Ag NPs caused more disturbance with plasma $\mathrm{Na}^{+}$falling below $100 \mathrm{mmol}^{-1}$ (Table 1). This might be expected when the gill total Ag concentration was also higher than that in fish from the metal salt treatment. The loss of electrolytes from the blood and increased Hct are consistent with osmotic swelling of the red blood cells. Johari and Kalbassi (2016) also reported elevated Hct and sodium depletion in trout during a 21d day exposure to the same Ag NP concentration used here; although an Ag NP effect cannot be deduced from their study because there was no silver salt control in their study design or data presented on dissolution.

The percentage of erythrocytes in the blood smears also decreased (Table 2), suggesting that osmotically damaged red cells in the circulation were not being replaced by the spleen. There was no pathology in the spleen (see below) and the amount of red pulp within the spleen was normal and did not decrease with either form of silver exposure. This is consistent with biologically modest disturbances to the red blood cells that were not sufficient to initiate a splenic response, and was therefore within the physiological tolerance of the fish. The Hct values reported here, despite some statistical difference, are consistent with values for the normal range in trout (Handy et al., 1999). Furthermore, as the Hct values increased without a change in total $\mathrm{Hb}$ concentration, it is unlikely that the haematology is an artefact of a hypoxic response through gill damage.

A significant increase in plasma $\mathrm{K}^{+}$was observed in fish from the $\mathrm{Ag}$ $\mathrm{NP}$ treatment, but not in the $\mathrm{AgNO}_{3}$-exposed fish by the end of the experiment. Rises in plasma $\mathrm{K}^{+}$concentrations are associated with vascular inflammation resulting from the loss of electrolytes (i.e., mainly $\mathrm{K}^{+}$) from leaky muscle which makes up the bulk of the animal. This has been demonstrated in both metal and NP exposures (metals in shellfish: Cd, Sheir and Handy, 2010; Cu NP in trout, Al-Bariuty et al., 2013). Regardless, taken together, the greater loss of plasma $\mathrm{Na}^{+}$, elevated plasma $\mathrm{K}^{+}$ and increased Hct suggested that the effects of the Ag NPs were greater than that of the $\mathrm{AgNO}_{3}$ exposure.

The morphology of the blood smears of fish were consistent with the haematology with the control and dispersant controls showing no evidence of swollen red blood cells, although there was some mild cell swelling in both silver treatments this was not statistically significant. There was also no effect of treatment on the number of shrunken cells or cells with a dividing nucleus. In addition, no particle aggregates were observed on the blood smears.

\subsection{Splenic functions in the haematopoietic system}

The spleen functions to ensure the composition and health of the circulating blood cells remain normal. It therefore has a role in the response to hypoxia with respect to maintain the number of circulating erythrocytes for the oxygen carrying capacity of the blood, but it also has an immune role in managing the circulating white cells (Handy et al., 2011). The total white cell counts in the blood were normal (Table 1 ), as were the proportions of white cells in the blood smears (Table 2), suggesting the spleen was maintaining the circulating white cells. There are few reports of white cell counts during in vivo Ag NP exposures in trout. Imani et al. (2015) reported elevation of white blood cell counts following exposure to $200 \mu \mathrm{g} 1^{-1} \mathrm{Ag}$ NPs for eight days in trout. However, the changes, although statistically significant, were within the normal range for trout and unfortunately a metal salt control was not included in their study design or total silver measurements in the tissues to confirm the exposure.

Toxic metals are known to alter the response of the immune system in several ways, including excess immunostimulation and inflammation, or immunosuppression (e.g., Dobrovolskaia and McNeil, 2007). These concerns are also applied to metallic NPs since they are both metal and a foreign particle (potential antigen; Zolnik et al., 2010). In the present study, there was no evidence for excessive immunostimulation (e.g. congestion of blood or tissues with white cells, Sheir and Handy, 2010), or spleen pathology indicative of inflammation. Similarly, the absence of increases in TBARS in the spleen at day 7 and no treatment-dependent changes in total GSH also indicate that inflammation with the associated oxidative stress did not occur. Bruneau et al. (2016) also observed no elevation of TBARS in trout exposed to $40 \mu \mathrm{g} 1^{-1} \mathrm{Ag}$ NPs for $96 \mathrm{~h}$ in gill or liver tissue, but did show an increase of cyclo-oxygenase activity in liver which could be a sign of emerging systemic oxidative stress.

The increase in melanomacrophage deposits of the spleen in Ag NP exposed fish (Fig. 3) suggests that the spleen had been coping with more housekeeping of debris from the turnover of blood cells. In addition, a transient elevation of thrombocytes was observed in the spleen prints only from the Ag NP-exposed fish. These cells secrete factors that are involved in the formation of the major histocompatibility complex (MHC) required for antigen recognition in fish (Köllner et al., 2004). Whether or not this indicates if the thrombocytes in the spleen were beginning to recognise Ag NP particles as antigen, or just responding to 
the general debris in the tissue (Handy et al., 2011) cannot be deduced from the measurements here.

The spleen prints also showed a decrease in the number of lymphocytes in the $\mathrm{Ag} \mathrm{NPs}$ and $\mathrm{AgNO}_{3}$-exposed fish, as well as the dispersant control (Table 3). For the Ag NP treatment this effect could be entirely explained by the dispersing agent, but agents such as Tween tend to have non-specific effects on membrane fragility, and yet the dispersant control did not alter the other cell counts in the spleen. The $\mathrm{AgNO}_{3}$ treatment showed a clear decline in lymphocytes in the spleen, but normal proportions in the blood smears from the circulation. This suggests the Ag was having an immune effect on lymphocytes, but it was readily managed by the spleen. The trout spleen contains several sub-populations of lymphocytes that are loosely analogous to mammalian T- and B-lymphocytes (Deluca et al., 1983). Further work would be needed on these sub-populations to determine the nature of the response.

\subsection{Conclusions, water quality and environmental implications}

Sub-lethal concentrations of Ag NPs did not cause adverse effects on the spleen or immune cells of trout in the short term with the experimental conditions used here. An acute hypersensitivity reaction with inflammation is also excluded. The early concerns that NPs, including Ag NPs, may be antigenic in mammals are not substantiated in this study for fishes. There are, however, some subtle differences between the effects of $\mathrm{Ag}$ as $\mathrm{AgNO}_{3}$ and $\mathrm{Ag} \mathrm{NPs}$, with the latter altering more haematological and splenic endpoints. This might suggest the environmental hazard of immunotoxicty is a little greater with exposure to the NP form. However, the mass dose of total Ag must be considered. The fish were exposed to at least an order of magnitude more Ag in the NP than dissolved form in this study to elicit a sub-lethal response. Despite the substantial disparity in exposure dose, there were only modest difference between $\mathrm{AgNO}_{3}$ and $\mathrm{Ag}$ NPs in terms of the biological importance of the endpoints; which were largely well within the physiological capability of the fish. Consequently, the current silver ion risk assessment is probably going to be protective for immune health during $\mathrm{Ag}$ NP exposures, at least in the short term in freshwater.

\section{Acknowledgements}

Nathaniel Clark conducted these studies as part of the MRes Marine Biology programme at Plymouth University. Dr Benjamin Shaw was supported by the E.C. MARINA Project, Call identifier: FP7-NMP-2010-LARGE-4, Grant Agreement No: NMP4-LA-2011-263215 (MARINA). Special thanks to the technical staff at Plymouth University: Andrew Atfield, William Vevers, Andrew Fisher and Mike Hockings.

\section{Appendix A. Supplementary material}

Supplementary data associated with this article can be found in the online version at doi:10.1016/j.ecoenv.2018.01.030.

Table 3

Quantitative analysis of spleen prints from rainbow trout exposed to $1 \mu \mathrm{g} \mathrm{1^{-1 }} \mathrm{Ag}_{\text {as }} \mathrm{AgNO}_{3}$ or $100 \mu \mathrm{g} \mathrm{l}^{-1} \mathrm{Ag} \mathrm{NPs}$ for 4 or 7 days.

\begin{tabular}{|c|c|c|c|c|c|}
\hline Percent of & Time & Treatment & & & \\
\hline cells & (days) & Control & Dispersant & $1 \mu g 1^{-1} \mathrm{AgNO}_{3}$ & $100 \mu g 1^{-1} \mathrm{Ag} \mathrm{NP}$ \\
\hline \multirow[t]{3}{*}{ Hemoblast } & 0 & $15.19 \pm 4.36(6)$ & & & \\
\hline & 4 & $17.77 \pm 2.65(6)$ & $19.13 \pm 3.23(6)$ & $16.41 \pm 1.00(6)$ & $16.47 \pm 4.33(6)$ \\
\hline & 7 & $19.79 \pm 3.41(6)$ & $16.0 \pm 5.23(6)$ & $15.85 \pm 2.40(6)$ & $12.31 \pm 2.64$ \\
\hline \multirow[t]{3}{*}{ Progranulocytes } & 0 & $3.77 \pm 0.89(6)$ & & & \\
\hline & 4 & $3.11 \pm 0.88(6)$ & $5.88 \pm 1.65(6)$ & $4.71 \pm 0.83(6)$ & $3.48 \pm 0.79(6)$ \\
\hline & 7 & $4.34 \pm 1.12(6)$ & $3.69 \pm 0.84(6)$ & $3.10 \pm 0.56(6)$ & $3.67 \pm 1.17(5)$ \\
\hline \multirow[t]{3}{*}{ Erythroblasts } & 0 & $4.55 \pm 1.04(6)$ & & & \\
\hline & 4 & $2.29 \pm 0.46(6)$ & $3.35 \pm 0.77(6)$ & $3.30 \pm 0.43(6)$ & $3.32 \pm 0.94(6)$ \\
\hline & 7 & $2.59 \pm 0.71(6)$ & $2.06 \pm 0.42(6)$ & $0.87 \pm 0.21(6)^{\mathrm{T} 0}$ & $1.91 \pm 0.90(5)$ \\
\hline \multirow[t]{3}{*}{ Erythrocytes } & 0 & $61.03 \pm 2.72(6)$ & & & \\
\hline & 4 & $66.67 \pm 3.21(6)$ & $63.86 \pm 4.41(6)$ & $66.18 \pm 2.44(6)$ & $55.69 \pm 4.54(6)^{* \#}$ \\
\hline & 7 & $62.62 \pm 5.34(6)$ & $72.62 \pm 6.53(6)$ & $73.67 \pm 2.93(6)$ & $73.96 \pm 4.74(5)^{\mathrm{T}}$ \\
\hline \multirow[t]{3}{*}{ Lymphocytes } & 0 & $11.59 \pm 2.96(6)$ & & & \\
\hline & 4 & $6.60 \pm 0.96(6)$ & $1.73 \pm 0.64(6)^{*}$ & $2.51 \pm 0.72(6)^{*}$ & $2.44 \pm 0.89(6)^{*}$ \\
\hline & 7 & $1.0 \pm 0.39(6)^{\mathrm{T} 0}$ & $0.88 \pm 0.38(6)^{0}$ & $1.30 \pm 0.52(6)^{0}$ & $0.69 \pm 0.22(5)^{0}$ \\
\hline \multirow{3}{*}{ Macrophages } & 0 & $0.90 \pm 0.26(6)$ & & & \\
\hline & 4 & $1.33 \pm 0.54(6)$ & $1.21 \pm 0.44(6)$ & $1.96 \pm 0.38(6)$ & $2.59 \pm 0.60(6)$ \\
\hline & 7 & $0.85 \pm 0.31(6)$ & $0.90 \pm 0.53(6)$ & $0.45 \pm 0.16(6)^{\mathrm{T}}$ & $1.01 \pm 0.69(5)^{\mathrm{T}}$ \\
\hline \multirow[t]{3}{*}{ Neutrophils } & 0 & $0.87 \pm 0.23(6)$ & & & \\
\hline & 4 & $1.03 \pm 0.33(6)$ & $0.88 \pm 0.34(6)$ & $2.05 \pm 0.52(6)$ & $2.23 \pm 0.98(6)$ \\
\hline & 7 & $1.97 \pm 0.47(6)$ & $1.45 \pm 0.56(6)$ & $1.40 \pm 0.38(6)$ & $1.18 \pm 0.42(5)$ \\
\hline \multirow[t]{3}{*}{ Thrombocytes } & 0 & $0.59 \pm 0.24(6)$ & & & \\
\hline & 4 & $0.08 \pm 0.08(6)$ & $0.13 \pm 0.08(6)$ & $1.22 \pm 0.86(6)$ & $7.59 \pm 1.28(6)^{*+\# 0}$ \\
\hline & 7 & $2.54 \pm 0.53(6)^{\mathrm{T} 0}$ & $0.33 \pm 0.07(6)$ & $1.16 \pm 0.58(6)^{\mathrm{T}}$ & $0.76 \pm 0.47(5)^{*}$ \\
\hline
\end{tabular}

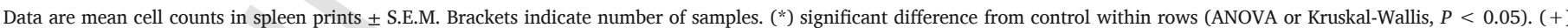

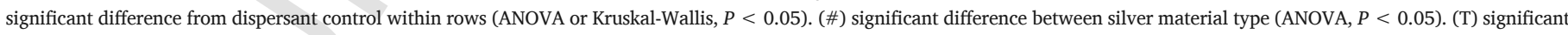
difference from day 4 data within treatment (ANOVA or Kruskal-Wallis, $P<0.05$ ). 


\section{References}

Al-Bariuty, G., Shaw, B.J., Handy, R.D., Henry, T.B., 2013. Histopathological effects of waterborne copper nanoparticles and copper sulphate on the organs of rainbow trout (Oncorhynchus mykiss). Aquat. Toxicol. 126, 104-115.

Besinis, A., De Peralta, T., Handy, R.D., 2014. The antibacterial effects of silver, titanium dioxide and silica dioxide nanoparticles compared to the dental disinfectant chlorhexidine on Streptococcus mutans using a suite of bioassays. Nanotoxicology 8, 1-16.

Bielmyer, G.K., Grosell, M., Paquin, P.R., Mathews, R., Wu, K.B., Santore, R.C., Brix, K.V., 2007. Validation study of the acute biotic ligand model for silver. Environ. Toxicol. Chem. 26, 2241-2246.

Boyle, D., Al-Bairuty, G.A., Henry, T.B., Handy, R.D., 2013. Critical comparison of intravenous injection of $\mathrm{TiO}_{2}$ nanoparticles with waterborne and dietary exposures concludes minimal environmentally-relevant toxicity in juvenile rainbow trout Oncorhynchus mykiss. Environ. Pollut. 182, 70-79.

Bruneau, A., Turcotte, P., Pilote, M., Gagné, F., Gagnon, C., 2016. Fate of silver nanoparticles in wastewater and immunotoxic effects on rainbow trout. Aquat. Toxicol. 174, 70-81.

Burke, J., Handy, R.D., Roast, S.D., 2003. Effect of low salinity on cadmium accumulation and calcium homeostasis in the shore crab (Carcinus maenas) at fixed free $\mathrm{Cd}^{2+}$ concentrations. Environ. Toxicol. Chem. 22, 2761-2767.

Bury, N.R., Galvez, F., Wood, C.M., 1999. Effects of chloride, calcium and dissolved organic carbon on silver toxicity: comparison between rainbow trout and fathead minnows. Environ. Toxicol. Chem. 18, 56-62.

Choi, J.E., Kim, S., Ahn, J.H., Youn, P., Kang, J.S., Park, K., Yi, J., Ryu, D.-Y., 2010. Induction of oxidative stress and apoptosis by silver nanoparticles in the liver of adult zebrafish. Aquat. Toxicol. 100, 151-159.

Deluca, D., Wilson, M., Warr, G.W., 1983. Lymphocyte heterogeneity in the trout, Salmo gairdneri, defined with monoclonal antibodies to IgM. Eur. J. Immunol. 13, 546-551.

Dobrovolskaia, M.A., McNeil, S.E., 2007. Immunological properties of engineered nanomaterials. Nat. Nanotechnol. 2, 469-478.

Duffin, R., Tran, L., Brown, D., Stone, V., Donaldson, K., 2007. Proinflammogenic effects of low-toxicity and metal nanoparticles in vivo and in vitro: Highlighting the role of particle surface area and surface reactivity. Inhal. Toxicol. 19, 849-856.

European Commission, 2011. Commission recommendation of 18 October 2011 on the definition of nanomaterial. Official Journal of the European Union (2011/696/EU)

Gottschalk, F., Sun, T.Y., Nowack, B., 2013. Environmental concentrations of engineered nanomaterials: review of modelling and analytical studies. Environ. Pollut. 181, 287-300.

Griffitt, R.J., Hyndman, K., Denslow, N.D., Barber, D.S., 2009. Comparison of molecular and histological changes in zebrafish gills exposed to metallic nanoparticles. Toxicol. Sci. 107, 404-415.

Handy, R.D., Depledge, M.H., 1999. Physiological responses: their measurement and use as environmental biomarkers in ecotoxicology. Ecotoxicology 8, 329-349.

Handy, R.D., Al-Bairuty, G., Al-Jubory, A., Ramsden, C.S., Boyle, D., Shaw, B.J., Henry, T.B., 2011. Effects of manufactured nanomaterials on fishes: a target organ and body systems physiology approach. J. Fish. Biol. 79, 821-853.

Handy, R.D., Sims, D.W., Giles, A., Campbell, H.A., Musonda, M.M., 1999. Metabolic trade-off between locomotion and detoxification for maintenance of blood chemistry and growth parameters by rainbow trout (Oncorhynchus mykiss) during chronic dietary exposure to copper. Aquat. Toxicol. 47, 23-41.

Hogstrand, C., Wood, C.M., 1998. Toward a better understanding of the bioavailability, physiology, and toxicity of silver in fish: implications for water quality criteria. Environ. Toxicol. Chem. 17, 547-561.

Hogstrand, C., Grosell, M., Wood, C.M., Hansen, H., 2003. Internal redistribution of radiolabelled silver among tissues of rainbow trout (Oncorhynchus mykiss) and European eel (Anguilla anguilla): the influence of silver speciation. Aquat. Toxicol. 63, 139-157.

Imani, M., Halimi, M., Khara, H., 2015. Effects of silver nanoparticles (AgNPs) on haematological parameters of rainbow trout, Oncorhynchus mykiss. Comp. Clin. Pathol. 24, 491-495.

Johari, S.A., Kalbassi, M.R., 2016. Chronic effect of waterborne colloidal silver nanoparticles on plasma biochemistry and hematology of rainbow trout (Oncorhynchus mykiss). J. Coast Life Med. 4, 337-340.

Johari, S.A., Kalbassi, M.R., Soltani, M., Yu, I.J., 2013. Toxicity comparison of colloidal silver nanoparticles in various life stages of rainbow trout (Oncorhynchus mykiss). Iran. J. Fish. Sci. 12, 76-95.
Jovanović, B., Palić, D., 2012. Immunotoxicology of non-functionalized engineered nanoparticles in aquatic organisms with special emphasis on fish - Review of curren knowledge, gap identification, and call for further research. Aquat. Toxicol. 118-119, 141-151.

Katuli, K.K., Massarsky, A., Hadadi, A., Pourmehran, Z., 2014. Silver nanoparticles inhibit the gill $\mathrm{Na}^{+} / \mathrm{K}^{+}$-ATPase and erythrocyte AChE activities and induce the stress response in adult zebrafish. Ecotoxicol. Environ. Saf. 106, 173-180.

Klaper, R., Arndt, D., Setyowati, K., Chen, J., Goetz, F., 2010. Functionalization impacts the effects of carbon nanotubes on the immune system of rainbow trout, Oncorhynchus mykiss. Aquat. Toxicol. 100, 211-217.

Köllner, B., Fischer, U., Rombout, J.H.W.M., Taverne-Thiele, J.J., Hansen, J.D., 2004. Potential involvement of rainbow trout thrombocytes in immune functions: a study using a panel of monoclonal antibodies and RT-PCR. Dev. Comp. Immunol. 28, 1049-1062.

Massarsky, A., Abraham, R., Nguyen, K.C., Rippstein, P., Tayabali, A.F., Trudeau, V.L., Moon, T.W., 2014. Nanosilver cytotoxicity in rainbow trout (Oncorhynchus mykiss) erythrocytes and hepatocytes. Comp. Bicohem. Physiol. C 159, 10-21.

Morgan, I.J., Henry, R.P., Wood, C.M., 1997. The mechanism of acute silver nitrate toxicity in freshwater rainbow trout (Oncorhynchus mykiss) is inhibition of gill $\mathrm{Na}^{+}$and $\mathrm{Cl}^{-}$transport. Aquat. Toxicol. 38, 145-163.

Peters, G., Schwarzer, R., 1985. Changes in hemopoietic tissue of rainbow trout under influence of stress. Dis. Aquat. Org. 1, 1-10.

Poland, C.A., Duffin, R., Kinloch, I., Maynard, A., Wallace, W.A.H., Seaton, A., Brown, S., MacNee, W., Donaldson, K., 2008. Carbon nanotubes introduced into the abdominal cavity of mice show asbestos-like pathogenicity in a pilot study. Nat. Nanotechnol. 3 , $423-428$.

Purcell, T.W., Peters, J.J., 1998. Sources of silver in the environment. Environ. Toxicol Chem. 17, 539-546.

Rice, C.D., 2001. Fish immunotoxicology. In: Schlenk, D., Benson, W.H. (Eds.), Target Organ Toxicity in Marina and Freshwater Teleosts Volume 2 - Systems. Taylor and Francis, London, UK, pp. 97-138.

Schinwald, A., Chernova, T., Donaldson, K., 2012. Use of silver nanowires to deter mine thresholds for fibre length-dependent pulmonary inflammation and inhibition of macrophage migration in vitro. Part. Fibre Toxicol. 9, https://doi.org/10.1186/ 1743-8977-9-47.

Scown, T.M., Santos, E.M., Johnston, B.D., Gaiser, B., Baalousha, M., Mitov, S., Lead, J.R., Stone, V., Fernandes, T.F., Jepson, M., van Aerle, R., Tyler, C.R., 2010. Effects of aqueous exposure to silver nanoparticles of different sizes in rainbow trout. Toxicol. Sci. $115,521-534$.

Shaw, B.J., Al-Bairuty, G., Handy, R.D., 2012. Effects of waterborne copper nanoparticles and copper sulphate on rainbow trout, (Oncorhynchus mykiss): physiology and accumulation. Aquat. Toxicol. 116-117, 90-101.

Shaw, B.J., Handy, R.D., 2011. Physiological effects of nanoparticles on fish: a comparison of nanometals versus metal ions. Environ. Int. 37, 1083-1097.

Shaw, B.J., Liddle, C.C., Windeatt, K.M., Handy, R.D., 2016. A critical evaluation of the fish early-life stage toxicity test for engineered nanomaterials: experimental modification and recommendations. Arch. Toxicol. 90, 2077-2107.

Sheir, S.K., Handy, R.D., 2010. Tissue injury and cellular immune responses to cadmium chloride exposure in the common mussel Mytilus edulis: modulation by lipopolysaccharide. Arch. Environ. Contam. Toxicol. 59, 602-613.

Smith, C.J., Shaw, B.J., Handy, R.D., 2007. Toxicity of single walled carbon nanotubes to rainbow trout, (Oncorhynchus mykiss): respiratory toxicity, organ pathologies, and other physiological effects. Aquat. Toxicol. 82, 94-109.

Smith, N.F., Talbot, C., Eddy, F.B., 1989. Dietary salt intake and its relevance to ionic regulation in freshwater salmonids. J. Fish. Biol. 35, 749-753.

Stone, V., Nowack, B., Baun, A., van den Brink, N., von der Kammer, F., Dusinska, M., Handy, R., Hankin, S., Hassellöv, M., Joner, E., Fernandes, T.F., 2010. Nanomaterials for environmental studies: classification, reference material issues, and strategies for physico-chemical characterisation. Sci. Total Environ. 408, 1745-1754.

Weibel, E.R., Kistler, G.S., Scherle, W.F., 1966. Practical stereological methods for morphometric cytology. J. Cell Biol. 30, 23-38.

Wood, C.M., Hogstrand, C., Galvez, F., Munger, R.S., 1996. The physiology of waterborne silver toxicity in freshwater rainbow trout (Oncorhynchus mykiss) 1 . The effects of ionic $\mathrm{Ag}^{+}$. Aquat. Toxicol. 35, 93-109.

Zolnik, B.S., González-Fernández, A., Sadrieh, N., Dobrovolskaia, M.A., 2010. Mini review: nanoparticles and the immune system. Endocrinology 151, 458-465. 